\title{
Investigating elementary school students' technology acceptance by applying digital game-based learning to environmental education
}

\author{
Yuh-Ming Cheng \\ Shu-Te University, Taiwan \\ Shi-Jer Lou \\ National Pingtung University of Science and Technology, Taiwan \\ Sheng-Huang Kuo \\ Shu-Te University, Taiwan \\ Ru-Chu Shih \\ National Pingtung University of Science and Technology, Taiwan
}

\begin{abstract}
In order to improve and promote students' environmental knowledge, attitudes, and behaviour, integrating environmental education into the primary education curriculum has become a key issue for environmental education. For this reason, this study aimed to investigate elementary school students' acceptance of technology applying digital gamebased learning (DGBL) to environmental education. A total of 32 fourth graders in an elementary school participated in a seven-week DGBL teaching experiment. After the experimental teaching session, a survey concerning "perceived ease of use", "perceived usefulness", and "user intentions" was conducted. The results show that the DGBL system is suitable for both genders at all levels of experience. In addition, the 4th grade students' "perceived ease of use", "perceived usefulness", "attitudes toward use", and "intention to use" reveal a high degree of positive and significant correlations. Furthermore, a path analysis verifies that DGBL acceptance will be directly influenced by a learner's "attitude toward use" and "perceived usefulness." Finally, when designing DGBL for 4th graders, the rich learning content and ease of use should be taken into account because they significantly contribute to a learner's intention to use the system, which may result in greater learning effectiveness.
\end{abstract}

\section{Introduction}

When Typhoon Morakot slammed into Taiwan at midnight on August 8, 2009, almost the entire southern region of Taiwan and parts of central Taiwan were flooded by record-breaking heavy rain. The typhoon wrought catastrophic damage, leaving 677 people dead and 22 others missing (including a single mudslide that buried the entire town of Xiaolin, killing an estimated 500 people) and causing roughly NT\$199 billion ( $\$ 6.9$ billion USD) in damages (Reconstruction Council, 2009). Since then, environmental education has become an important part of both the secondary and primary school curricula. In particular, incorporating environmental education into the primary education curriculum has become a key issue (Hsu, 2005; Huang \& Lin, 2008; Ürey, Çolak, \& Okur, 2009; Yurttaş \& Sülün, 2010; Zhang \& Ye, 2010).

Environmental education has a half-century of history in the United States, yet it is still emerging as a professional field (Crohn \& Birnbaum, 2010); more recently, it has assumed the characteristics of an emerging profession (Heimlich, 2010). Although environmental change is serious, urgent, and increasing, Disinger (1997) claims that environmental education is often non-formal, which implies that much of the education is performed beyond the confines of schools. In particular, much of the focus is on youth. Crohn and Birnbaum (2010) believe that the goal of many environmental education-based efforts targeted at youth is to change a child's relationship with nature. Furthermore, some researchers have shown that multimedia can increase students' motivation and improve their learning attitudes. Chang, Chen, and Hsu (2011) also suggest that although improving and promoting environmental knowledge, attitude, and behaviour is a common goal, different teaching or training methods are applied in different places. With greater Internet usage, online games have become increasingly popular. According to a prior study, $40 \%$ of Internet users in Taiwan have played online games (Hsu and Lu, 2007). Hence, "playing a game" is 
only one of several possible strategic responses that environmental educators might pursue (Gruenewald \& Manteaw, 2007). Garris, Ahlers, and Driskell (2002) suggest that instructional content and game characteristics should be incorporated via digital game-based learning (DGBL) to allow learners to be involved in the game and to accomplish various learning goals.

Therefore, this study aimed to apply DGBL to environmental education to investigate the degree of acceptance among 4th grade elementary school students. According to standard practice, the researcher constructed variables to fully explore students' perceived ease of use and perceived of the system as well as their intention to use the system. The following five questions were posed:

Question 1: Are there any significant differences in the factors across demographic factors?

Question 2: What are the factors influencing learners' intention to use DGBL?

Question 3: How do the factors influence learners' intention to use DGBL?

Question 4: What is the learners' acceptance of DGBL?

Question 5: What is the learning effectiveness of environmental education in this study?

\section{Literature Review}

Currently, computer games have become one of the preferred online activities for teenagers (Stefanescu, Chirita, Chirita, \& Chele, 2007). Zhi and Zhenhong (2008) point out that the most popular computer games include role-playing games, real-time strategy games, shooting and fighting games, adventure games, action games, puzzle games, and chess games. Cankaya and Kuzu (2010) note that children learn by playing and having fun. Playing gives the opportunity to make mistakes without getting harmed. In this way, people learn through their experiences by making mistakes. However, Vygotsky argues that games contribute to cognitive development in important ways instead of simply reflecting cognitive development (Nicolopoulou, 2004). Thus, educational computer games, which include the motivational and fun features of computer games, can be used as an alternative or complement to other instructional methods to achieve instructional or educational goals (Cankaya \& Karamete, 2009).

Digital game-based learning (DGBL) is a particular type of game-based learning, as outlined by Prensky (2001). It closely combines educational content and games on computers or online to stimulate learners' interest and provide them with the opportunity for continuous learning as well as ultimately to enhance their learning effectiveness. Digital games, an interactive technology within the multimedia learning environment, could foster an effect learning process, especially among young learners. Latif (2007) mentions that digital games, such as video or computer games, are widely accepted among children and teenagers. Recently, digital games have been used in an area called educational games. Educational games are widely used as a teaching and learning tool in some subjects, such as mathematics, science, history, and language learning (Zin, Jaafar, \& Yue, 2009). Recently, many scholars have noticed that DGBL has gradually become the new approach for learning (Aldrich, 2004; Squire \& Steinkuehler, 2005). Previous studies reveal that the use of games in education is perceived as a useful tool for learning, as they enable teachers to engage students in educational experiences to achieve specific learning goals and outcomes (Garcia-Barcena, \& Garcia-Crespo, 2006; Vasiliou, \& Economides, 2007). Gros (2007) also points out that digital games can promote learners' engagement, cooperation, and the development of problem-solving strategies. Additionally, some studies reveals that digital game-based learning systems can significantly promote learners' self-awareness, learning motivation, and willingness (Cheng, Kuo, Lou, \& Shih, 2012; Yang, Chien, \& Liu, 2012). However, an ideal digital game that incorporates instructional content and game characteristics of DGBL can allow learners involved in the game to accomplish specific learning goals and learn effectively.

To examine the behaviour of information technology users, Davis, Bagozzi, and Warshaw (1989) adopt the Theory of Reasoned Action (TRA) in psychology research and then incorporate information system use to develop the theoretical framework for the technical acceptance model (TAM). The theory is commonly applied to the study of human behavioural intention (Fishbein \& Ajzen, 1975). Behavioural intention is influenced by a person's attitude toward the behaviour and by subjective criteria (Davis, 1989; Lai, Huang, Liaw, and Huang 2009). Davis (1989) further adopted the belief-attitude-intention-behaviour causal chain to predict user acceptance of information technology (IT). Over the past decade, researchers have applied the TAM model to examine IT usage and have verified that user perceptions of both perceived usefulness and perceived ease-of-use are key determinants of individual technology adoption. 
Lee, Kozar, and Larsen (2003) stated that the TAM can be and has been used to test user acceptance of a wide variety of technologies. Ngai, Poon, and Chan (2007) also note that "TAM is for user acceptance of technology."

TAM was developed to explain computer-usage behaviour and factors associated with acceptance of technology. It has been used to test the acceptance of various technologies or software used in teaching and/or learning within a student context (Shroff, Deneen, \& Ng, 2011). Similar views on the validity of DGBL have been demonstrated in many studies (Amoako-Gyampah \& Salam, 2004; Hong, Hwang, Hsu, Wong, and Chen 2011; Lederer, Maupin, Sena, and Zhuang 2000; Pai \& Huang, 2011; Polancic, Hericko, \& Rozman, 2010; Tao, Cheng, \& Sun, 2009). TAM can be applied to explore the influence of external factors (e.g., characteristics of the system design, computer self-efficacy, and system interaction) on users' internal beliefs, attitudes, and intentions as well as on technology use (Davis, 1986). In short, TAM demonstrates that perceived ease of use and perceived usefulness will both influence attitudes toward technology use and affect intentions to use technology.

Environmental education was first introduced in 1966 (Schoenfeld, 1975). A few years later, Stapp (1969) and colleagues at the University of Michigan presented papers on the concept of environmental education in 1969. As Ramsey and Hungerford (1989) eloquently argue, the most important goal of environmental education is to develop responsible environmental behaviour. Relying upon extensive research in the field of environmental education, Chang, et al. (2011) indicate that to improve and promote people's environmental knowledge, attitudes, and behaviour, many studies have applied different teaching or training methods in different places. For example, according to the learning-by-doing theory, learning is a process in which knowledge is acquired through the transformative experience (Dewey, 1938; Kaagan, 1999). With respect to environmental education, studies by Ajiboye and Silo (2008), Carleton-Hug and Hug (2010), and Uzunboylu, Cavus, and Ercag (2009) indicate that the environmental awareness of participants increased significantly, and attitudes toward maintaining a clean environment and preventing pollution improved. It follows, then, that introducing multimedia applications can increase students' motivation and improve their learning attitudes. Indeed, Chang, et al. (2011) conclude that schools already apply information technology and encourage teaching initiatives to achieve creative ways of instructing students, thereby improving students' ability to absorb environmental education. From this perspective, applying digital game-based learning (DBGL) with TAM to environmental education may help alleviate one of today's fundamental challenges for environmental education as well as to increase the youth's awareness and practice of environmental education.

\section{Research Method}

This study aims to evaluate acceptance by 4th grade elementary school students of DGBL for instruction in environmental education. The research framework is constructed according to the relevant literature, as shown in Figure 1. Variables include students' perceived ease of use, perceived usefulness, and intention to use the system, as well as students' individual differences.

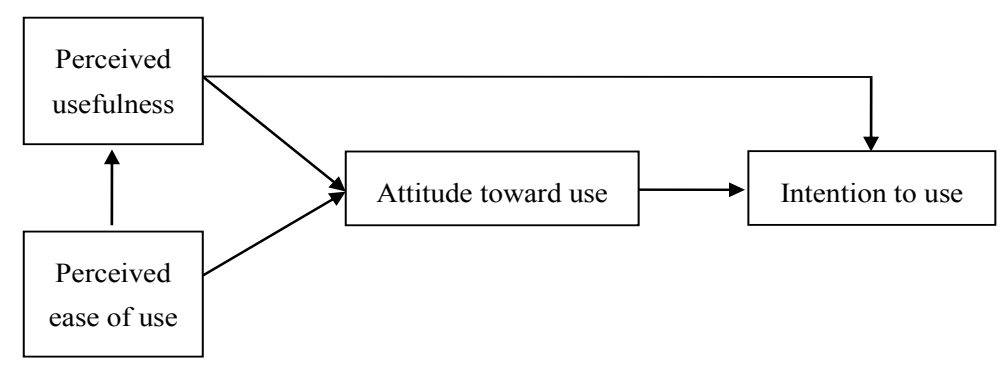

Figure 1. Technology Acceptance Model.

The case study is used in the experimental study in an elementary school in southern Taiwan for a 7-week DGBL experimental teaching of environmental education. A total of 32 fourth-grade elementary students participated in this study. Prior to the experiment, the 32 students already possessed basic computer skills and were advised to apply for accounts as well as to practice the manipulation of the DGBL system. The content of the DGBL system was adopted from the indicators of environmental education released by the nine-year program, Ministry of Education, Taiwan. The rules of the game were similar to Monopoly. 
Students formed their groups by inviting two to four people online. The content of all questions related to environmental education. To gain points, the students needed to answer questions correctly. The computer calculated the amount of tokens at the end of the game to determine the winning group. The entry pages of the DGBL system are shown in Figure 2.

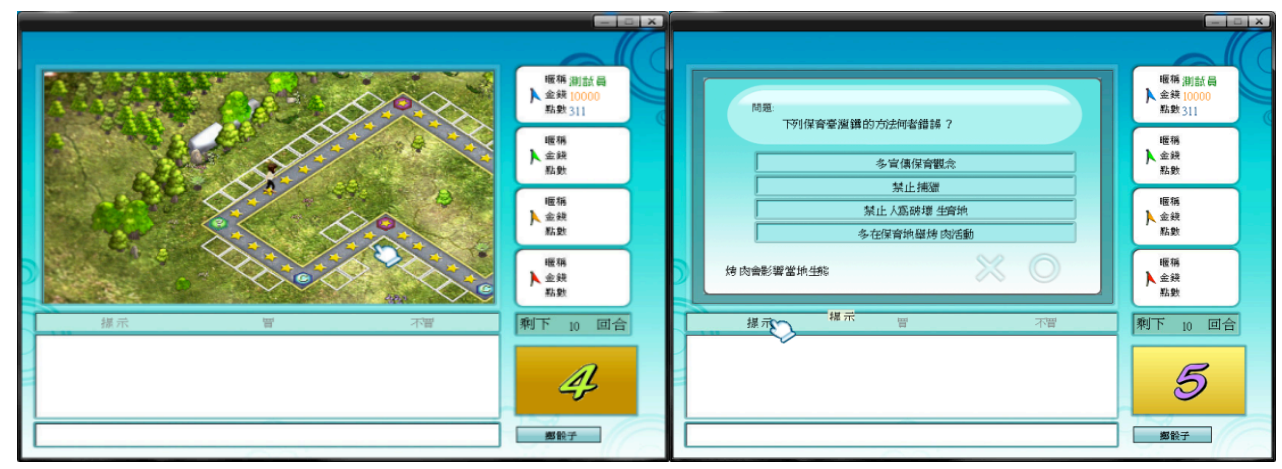

Figure 2. The entry of game playing and answering in the DGBL system.

After the experimental teaching, a survey was conducted according to the revised scales of Davis et al. (1989) and Lai et al. (2009). Scaling for acceptance toward application of digital game-based learning to environmental education, the researchers employed the Likert 5-point scale ( $1=$ strongly disagree, $5=$ strongly agree). After expert validity, item analysis, and factor analysis, 3 dimensions and 12 items were obtained: "perceived ease of use" (4 items), "perceived usefulness" (4 items), "attitude toward use" (4 items), and "intention to use" (4 items). The results of Cronbach's $\alpha$ test on the sub-scale and total scale obtained $.828, .823, .833$, and .815 on the sub-scale and. 940 on the total scale, indicating the scale is considerably reliable.

The collected data were analysed using the statistical methods, including descriptive statistics, independent t-test, stepwise multiple regression analysis, Pearson product-moment correlation analysis, and path analysis. The descriptive analysis was used to analyse gender, self-study, and the experience of DGBL use. The independent t-test was employed to test the acceptance toward application of DGBL in environmental education among the samples. Stepwise multiple regression and Pearson product-moment correlation were used to examine the correlations among perceived ease of use, perceived usefulness, attitude toward use, and intention to use. Path analysis was administered to draw the path diagram to understand the effect of "perceived ease of use", "perceived usefulness", "attitude toward use", and "intention to use."

Additionally, interviews with the 32 students were conducted after the 7-week experimental teaching to further elucidate the students' technology acceptance and learning effectiveness of DGBL in environmental education. All excerpts of the student interviews were summarized with codes from S1 to S32.

\section{Data Analysis and Results}

The researchers used SPSS for Windows 12.0 to analyse the collected data from the survey. The findings are discussed in the following sections.

\section{Descriptive statistics analysis}

According to Table 1, the participants consist of 15 male students (46.9\%) and 17 female students (53.1\%). Meanwhile, there are 21 students in the yes group of self-taught to use a computer $(65.6 \%)$ and 11 in the no group of self-taught to use a computer (34.4\%). Finally, there are 7 in the yes group of experience with DGBL $(21.9 \%)$ and 25 in the no group of experience with DGBL $(78.1 \%)$. 
Table 1:

Descriptive statistics of different background variables

\begin{tabular}{llll}
\hline Background variables & Group & Number of people & Percentage \\
\hline \multirow{2}{*}{ Gender } & Male & 15 & $46.9 \%$ \\
& Female & 17 & $53.1 \%$ \\
\multirow{2}{*}{ Self-taught to use a computer } & Yes & 21 & $65.6 \%$ \\
& No & 11 & $34.4 \%$ \\
Experience with DGBL & Yes & 7 & $21.9 \%$ \\
& No & 25 & $78.1 \%$ \\
\hline
\end{tabular}

\section{Differential analysis of different variables on acceptance of DGBL}

To examine the effect of differences in students' backgrounds on use intention of a DGBL system, this study adopted an independent sample t-test. The items analysed include gender, self-taught computer literacy, and experience with DGBL. The researchers attempted to determine if the influence of these items on "intention to use a DGBL system" was significantly different. The test result is shown in Table 2. Levene test outcomes of the participants' gender, self-taught knowledge of computer use and experience with DGBL on use intention to use are insignificant. Thus, according to Table 2, the t-test findings demonstrated that students' background variables do not have a significant effect on use intention of a DGBL system.

Table 2

Levene test, t-test results of variables on use intention of a DGBL system

\begin{tabular}{lllll}
\hline \multirow{2}{*}{ Variables } & \multicolumn{4}{c}{ Intention to use } \\
\cline { 2 - 5 } & Levene test & $\boldsymbol{p}$ & t- test & $\boldsymbol{p}$ \\
\hline Gender & .18 & .68 & -.37 & .71 \\
Self-taught computer literacy & .17 & .67 & -1.23 & .23 \\
Experience with DGBL & 1.08 & .31 & -.01 & .99 \\
\hline
\end{tabular}

\section{Regression analysis}

To determine whether "perceived ease of use" significantly predicts "perceived usefulness", this study treats "perceived usefulness" as a dependent variable and "perceived ease of use" as an independent variable.

According to Table 3, "perceived ease of use" can explain 53\% of the variation of "perceived usefulness." Regarding the adjusted R2, there is still $51 \%$ of explained power. F is 33.97 at $p=.000<.001$, which is significant. Based on the coefficient estimation in the stepwise analysis, the beta coefficient is 0.73 $(p=.000)$. This means that there is significant relationship between the independent variable ("perceived ease of use") and dependent variable ("perceived usefulness").

Table 3

Stepwise multiple regression analysis of "perceived ease of use" on "perceived usefulness"

\begin{tabular}{lcccccccccc}
\hline $\begin{array}{l}\text { Order of } \\
\text { variables }\end{array}$ & $\mathbf{R}$ & $\mathbf{R}^{2}$ & $\Delta \mathbf{R}^{2}$ & $\mathbf{F}$ & $\Delta \mathbf{F}$ & $\mathbf{B}$ & $\boldsymbol{\beta}$ & $\mathbf{T O L}$ & $\mathbf{V I F}$ & $\mathbf{C I}$ \\
\hline $\begin{array}{l}\text { Perceived } \\
\text { ease of use }\end{array}$ & .73 & .53 & .52 & 33.97 & $33.97^{* * *}$ & .93 & .73 & 1.00 & 1.00 & 15.87 \\
\hline Note. $^{* * *} p<.001$ & & & & & & & & &
\end{tabular}


In addition, "attitude toward use" is treated as a dependent variable. "Perceived ease of use" and "perceived usefulness" are independent variables. Therefore, the researchers attempted to determine whether "perceived ease of use" and "perceived usefulness" significantly predict the use intention. The statistical results in Table 4 explain $54 \%$ of the variation in the dependent variable. The adjusted R2 indicates $53 \%$ of explained power. $\mathrm{F}$ is 36.46 at $\mathrm{p}=.000<.001$, which is significant. Based on the coefficient estimation in the stepwise analysis, the beta coefficient is $.74(\mathrm{p}=.000)$. This means that there is significant relationship between the independent variable ("perceived ease of use" and "perceived usefulness") and the dependent variable ("use intention").

Table 4

Stepwise multiple regression analysis of perceived ease of use and perceived usefulness on attitude toward use

\begin{tabular}{lcccccccccc}
\hline $\begin{array}{l}\text { Order of } \\
\text { variables }\end{array}$ & $\boldsymbol{R}$ & $\boldsymbol{R}^{2}$ & $\boldsymbol{\Delta \boldsymbol { R } ^ { 2 }}$ & $\boldsymbol{F}$ & $\boldsymbol{\Delta} \boldsymbol{F}$ & $\boldsymbol{B}$ & $\boldsymbol{\beta}$ & $\boldsymbol{T O L}$ & $\boldsymbol{V I F}$ & $\boldsymbol{C I}$ \\
\hline $\begin{array}{l}\text { Perceived } \\
\text { ease of use }\end{array}$ & .73 & .53 & .52 & 33.89 & $33.89^{* * *}$ & .96 & .73 & 1.00 & 1.00 & 15.89 \\
$\begin{array}{l}\text { Perceived } \\
\text { usefulness }\end{array}$ & .74 & .55 & .53 & 36.46 & $36.46^{* * *}$ & .77 & .74 & 1.00 & 1.00 & 11.90 \\
\hline Note. $^{* * *} p<.001$ & & & & & & & &
\end{tabular}

Furthermore, "intention to use" is treated as the dependent variable and "perceived usefulness" and "attitude toward use" are independent variables. Consequently, the researchers attempted to determine whether "perceived usefulness" and "attitude toward use" significantly predict "intention to use." According to Table 5, the statistical results explain $53 \%$ of the variation in the dependent variable. The adjusted R2 indicates $51 \%$ of explained power. $\mathrm{F}$ is 33.62 at $\mathrm{p}=.000<.001$, which is significant. Based on the coefficient estimation in the stepwise analysis, the beta coefficient is $0.73(\mathrm{p}=0.000)$. This means that there is a significant relationship between the independent variable ("perceived ease of use" and "perceived usefulness") and the dependent variable ("intention to use").

Table 5

Stepwise multiple regression analysis of "perceived ease of use" and "perceived usefulness" on "intension to use"

\begin{tabular}{lllllllllll}
\hline $\begin{array}{l}\text { Order of } \\
\text { variables }\end{array}$ & $\boldsymbol{R}$ & $\boldsymbol{R}^{2}$ & $\boldsymbol{\Delta R}^{2}$ & $\boldsymbol{F}$ value & $\boldsymbol{\Delta} \boldsymbol{F}$ & $\boldsymbol{B}$ & $\boldsymbol{\beta}$ & $\boldsymbol{T O L}$ & $\boldsymbol{V I F}$ & $\boldsymbol{C I}$ \\
\hline $\begin{array}{l}\text { Perceived } \\
\text { usefulness }\end{array}$ & .76 & .58 & .57 & 41.61 & $41.61^{* * *}$ & .70 & .76 & 1.00 & 1.00 & 11.90 \\
$\begin{array}{l}\text { Attitude } \\
\text { toward use }\end{array}$ & .73 & .53 & .51 & 33.62 & $33.62^{* * *}$ & .64 & .73 & 1.00 & 1.00 & 11.08 \\
\hline Note ${ }^{* * *} p<.001$ & & & & & & & &
\end{tabular}

Note. ${ }^{* * *} p<.001$

\section{Path analysis}

To further clarify the relationships among the variables using a path analysis, this study constructs the path of intention to use" a DGBL system. A literature review and a product-moment correlation matrix of learners' different variables function were used as criteria to construct a causal model.

According to Table 6, the Pearson product-moment correlation among "perceived ease of use", "perceived usefulness", "attitude toward use", and "intention to use" reveals a significant, higher and positive correlation. The product-moment correlation between "perceived ease of use" and "perceived usefulness" is $\mathrm{r}(30)=.73, \mathrm{p}<.001$; the product-moment correlation between "perceived ease of use" and "attitude toward use" is $\mathrm{r}(30)=.73, \mathrm{p}<.001$; the product-moment correlation between "perceived ease of use" and "intention to use" is $\mathrm{r}(30)=.79, \mathrm{p}<.001$; the product-moment correlation between "perceived usefulness" and "attitude toward use" is $\mathrm{r}(30)=.74, \mathrm{p}<.001$. The product-moment correlation between "perceived usefulness" and "intention to use" is $\mathrm{r}(30)=.76, \mathrm{p}<.001$. The product-moment correlation between "attitude toward use" and "intention to use" is $\mathrm{r}(30)=.73, \mathrm{p}<.001$. 
Based on the above findings, there is a high degree of positive and significant correlation between students' perceived ease of use, perceived usefulness, attitude toward use, and intention to use.

Table 6

Pearson product-moment correlation matrix of "perceived ease of use", "perceived usefulness", "attitude toward use", and "intention to use"

\begin{tabular}{lllll}
\hline Variables & $\mathbf{1}$ & $\mathbf{2}$ & $\mathbf{3}$ & $\mathbf{4}$ \\
\hline 1. Perceived ease of use & - & & & \\
2. Perceived usefulness & $.73^{* * *}$ & - & & \\
3. Attitude toward use & $.73^{* * *}$ & $.74^{* * *}$ & - & \\
4. Intention to use & $.79^{* * *}$ & $.76^{* * *}$ & $.73^{* * *}$ & - \\
$M$ & 16.09 & 15.31 & 14.78 & 16.97 \\
$S D$ & 2.07 & 2.63 & 2.73 & 2.42 \\
\hline
\end{tabular}

Note. $n=32 .{ }^{* * *} p<.001$

Therefore, based on relevant theoretical bases in the literature review and the product-moment correlations among the variables in Table 6, the path of the full model is constructed (see Figure 5). Causal relationships among the variables are shown by arrows. The starts of arrows indicate "causes" and the variables pointed at by arrows are "effects."

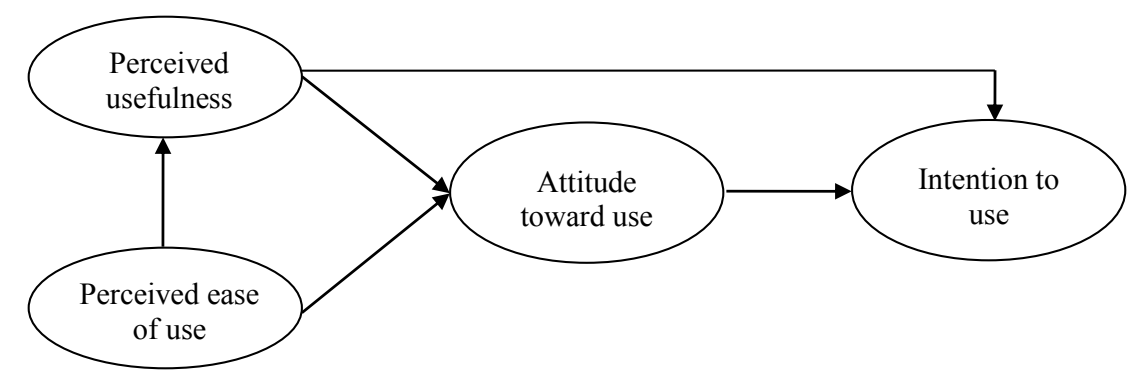

Figure 5. Path of the DGBL application to environmental education acceptance model.

The outcome of the path analysis of the restriction model is shown in Table 7, which demonstrates that the $t$ values of all paths are statistically and significantly different.

Table 7

Path analysis of restriction model of DGBL applied to environmental education acceptance

\begin{tabular}{lllllll}
\hline Criterion & Predictors & $\boldsymbol{\beta}$ & $\boldsymbol{t}$ & $\boldsymbol{R}^{2}$ & $\begin{array}{l}\text { Residual } \\
\text { Variable }\end{array}$ & $\boldsymbol{F}$ \\
\hline \multirow{2}{*}{ Intention to use } & Attitude toward use & .50 & $2.99^{* *}$ & .62 & .62 & $25.71^{* * *}$ \\
& Perceived usefulness & .36 & $2.17^{*}$ & & & \\
Attitude toward use & Perceived ease of use & .40 & $2.42^{*}$ & .60 & .63 & $24.11^{* * *}$ \\
& Perceived usefulness & .45 & $2.69^{*}$ & & & \\
Perceived usefulness & Perceived ease of use & .79 & $5.83^{* * *}$ & .52 & .70 & $33.97^{* * *}$ \\
Note. ${ }^{*} p<.05 .{ }^{* *} p<.01 .{ }^{* * *} p<.001$ & & & & &
\end{tabular}




\section{Effective Estimation of Perceived Ease of Use on Intention to Use}

The relationships analysed in the path analysis and depicted in Figure 6 were examined in detail:

Path 1: Perceived Ease of Use $\rightarrow(.79)$ Perceived Usefulness $\rightarrow(.36)$ Intention to Use $=.79 \times .36=.28$

Path 2: Perceived Ease of Use $\rightarrow(.40)$ Attitude toward Use $\rightarrow(.50)$ Intention to Use $=.40 \times .50=.20$

Path 3: Perceived Ease of Use $\rightarrow(.79)$ Perceived Usefulness $\rightarrow(.45)$ Attitude toward Use $\rightarrow(.50)$ Intention to Use

$=.79 \times .45 \times .50=.18$

Total indirect effect $=.28+.20+.18=.66$

The indirect effect of "perceived ease of use" on "intention to use" was estimated at $.28(.79 \times .36)$. The effect was through "perceived usefulness." The indirect effect of "perceived ease of use" on "intention to use" was also estimated to be $.20(.40 \times .50)$. The effect was through "attitude toward use." The indirect effect of "perceived ease of use' on "intention to use" was estimated to be $.18(.79 \times .45 \times .50)$. The effect was through "perceived usefulness" and "attitude toward use." The total indirect effect of "perceived ease of use" on "intention to use" was estimated to be $.66(.28+.20+.18)$.

\section{Effective Estimation of Perceived Usefulness on Intention to Use}

Path 1: Perceived Usefulness $\rightarrow(.36)$ Intention to Use

Path 2: Perceived Usefulness $\rightarrow(.45)$ Attitude toward Use $\rightarrow(.50)$ Intention to Use

$=.45 \times .50=.23$

Total indirect effect $=.36+.23=.59$

The direct effect of "perceived usefulness" on "intention to use" was estimated at .36. The indirect effect of "perceived usefulness" on "intention to use" was also estimated at $.23(.45 \times .50)$. The effect was through attitude toward use. The total effect (both direct and indirect) of "perceived usefulness" on "intention to use" was estimated to be $.59(.36+.23)$.

\section{Effective Estimation of Attitude toward Use on Intention to Use}

Path: Attitude toward Use $\rightarrow(.50)$ Intention to Use. The direct effect of Attitude toward Use on Intention of Use was estimated to be .50 .

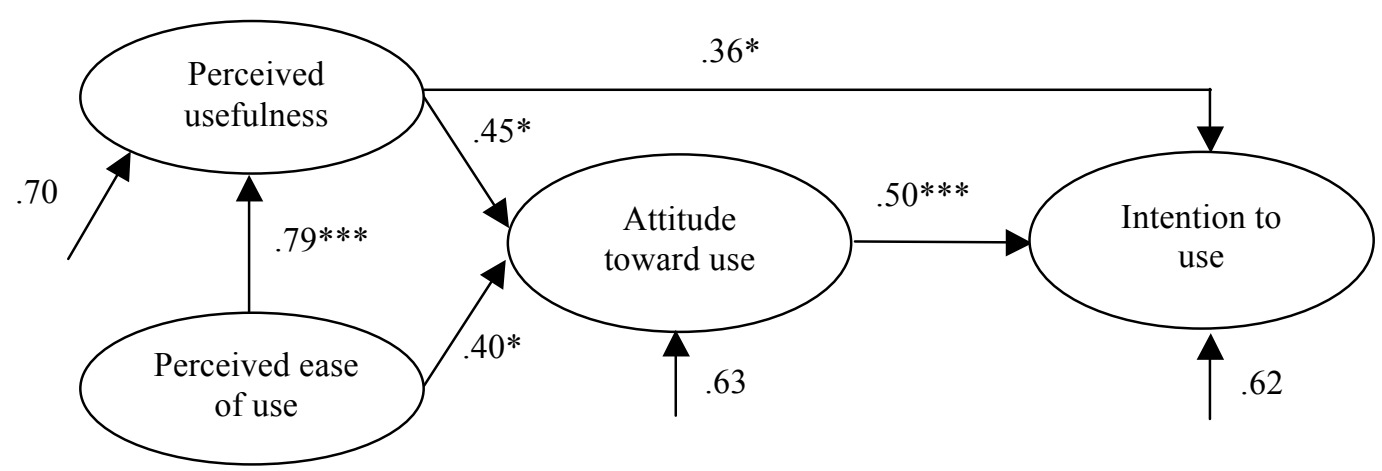

Figure 6. Path of restriction model of DGBL applied to environmental education acceptance. 
The relationships between the three variables ("perceived ease of use", "perceived usefulness", and "attitude toward use") and "intention to use" were summarily presented in Table 8.

Table 8

Summary of estimated direct and indirect effects

\begin{tabular}{llll}
\hline Relationships (Paths) & $\begin{array}{l}\text { Direct } \\
\text { effect } \\
\mathbf{( 1 )}\end{array}$ & $\begin{array}{l}\text { Indirect } \\
\text { effect } \\
\mathbf{( 1 )}\end{array}$ & $\begin{array}{l}\text { Total } \\
\text { effect } \\
(\mathbf{1 + 2})\end{array}$ \\
\hline 1 Perceived Ease of Use $\rightarrow$ Intention to Use & & .66 & .66 \\
2 Perceived Usefulness $\rightarrow$ Intention to Use & .36 & .23 & .59 \\
3 Attitude Toward Use $\rightarrow$ Intention to Use & .50 & & .50 \\
\hline
\end{tabular}

Table 8 shows the estimated direct and indirect effects among the variables in the path analysis model. The direct effect of "attitude toward use" on "intention to use" from this model is .50. This means that unit change in "attitude toward use" leads to a .50 unit change in "intention to use." Similarly, the direct effect of "perceived usefulness" on "intention to use" from this model is .36, indicating unit change in "perceived usefulness" leads to a .36 unit change in "intention to use." In addition to that direct effect, "perceived usefulness" has an indirect effect on "intention to use" with the strength of .23, which means that unit change in "perceived usefulness" leads to .23 unit change in "intention to use" through "attitude toward use."

The total effect of .66 means that a .66 predicted unit change in "intention to use" is due to unit change in the "perceived ease of use" when all the other variables in the model are left untouched. The total effect of .59 means that a .59 predicted unit change in "intention of use" is due to unit change in the "perceived usefulness" when all the other variables in the model are left untouched. The total effect of .50 means that a .50 predicted unit change in "intention to use" is due to unit change in the "attitude toward use" when all the other variables in the model are left untouched. The three internal variables ("perceived ease of use", "perceived usefulness", and "attitude toward use") have moderate effects (.66, .59, and .50, respectively) on intention to use.

A brief summary of the interviews with the 32 students is presented in the following section followed by some of the excerpts.

According to the interviews, in terms of the acceptance of DGBL, most of the students held great expectations toward the course. The monopoly game was familiar to them and fun when applied in the course. The students could do role plays in the game to compete with their classmates as well as to practice in the training room. Through DGBL, the students could also easily learn environment-related knowledge from role plays. They expected to complete and challenge their classmates through the online games. These reasons are why DGBL can enhance the students' motivation and interest and this DGBL with TAM teaching approach is effective for environmental education. Additionally, the low-achievers liked the environmental education course more after the DGBL instruction. Especially, the low achievers would take notes for every step in order to win the monopoly game. Furthermore, the course instructor also observed that the low achievers' grades improved from B to A. Finally, all the students realized and learned that it is urgent to care and protect our environment in order to slow down the global warming and climate change to save our earth.

\section{Students' comments}

- I want to win the game on the DGBL system. That's why I have been studying environmental education so hard. (S6)

- As a girl, I thought playing the game was the preserve of the male students. But I learned some knowledge from role playing the game. (S7)

- I hope that other courses can be taught just like this one. I can learn things and play games at the same time. (S1, S9)

- I used to get B or C on this subject. After using DGBL in this course, my motivation to learn has been enhanced. (S14) 
- This teaching approach is great because I can play the game and invite other online classmates to join the competition and to challenge other better players. Every week, I always look forward to the class day to come because I can challenge my classmates and to show my ability. (S15, S20)

- I was very excited about this DGBL teaching and learning system in the beginning. Friends from other classes envy me and wanted to join our class so bad. (S28, S30)

- I used to hate this class. After using the DGBL system, I like to come to class every day. (S1)

- It is very cool for the teacher to integrate Monopoly games into our environmental education class. (S2; S4)

- In order to pass every level of the game, I had to pay lots of attention to the teacher in the class and took lots of notes. (S3; S32)

- After playing this game, I learned that environmental education is not only about environmental protection, recycling, and protecting our planet issues, but also about ecology balance, respect for lives, and sustainable development. (S5, S12)

- I finally learned about issues in environmental education through this interesting, special teaching method. (S6, S11, S15)

- $\quad$ My dad told me that my grade had improved a lot. Thank you teacher. (S22, S25)

- I hope the class hours can be extended more. Thus, I can learn more about this issue. (S28)

- My grades have improved from B to A. I have to thank the teacher for providing such great learning and teaching software. (S32)

\section{Discussion}

The results of the present study show that a learner's gender, whether he/she is a self-taught computer user, or whether the learner had previous DGBL experience do not have a significant difference in terms of acceptance toward using the DGBL system. That learning through DGBL system was more effective than some other activities at supporting a higher cognitive presence was demonstrated by Papargyris and Poulymenakou (2004). In particular, it is believed that computer-mediated education may help society overcome one of today's fundamental challenges for environmental education, namely, learners' alienation from nature (Brämer, 2003; Van Velsor, 2004).

Three variables significantly influence the learners' intention of using DGBL. Moreover, the three variables, namely, perceived usefulness, perceived ease of use and attitude toward use, that had been identified as significant factors in TAM also proved to have a positive influence on learners' acceptance of DGBL. The results of the Pearson product-moment correlation among "perceived ease of use," perceived usefulness, attitude toward use, and intention to use reveals a significant, high, and positive correlation. Based on the above, learners' perceived ease of use, perceived usefulness, attitude toward use, and intention to use reveal a high degree of positive and significant correlation that it is quite similar to Pai and Huang (2011) and Teo (2010).

Three factors had positive effects on the learners' acceptance of DGBL. Only "perceived usefulness" had both indirect effects and direct effects on the learner's acceptance of DGBL and only "attitude toward use" had direct effects on the learners' acceptance of DGBL. A number of other researchers have obtained similar findings (e.g., Hong et al., 2011; Pai and Huang, 2011; Polancic, et al., 2010; Teo, 2010; Teo, Lee, Chai, and Wong 2009). Compared with the use of traditional instruction, the DGBL requires more time and energy from students to accomplish their learning tasks and engages higher level of thinking skills. Several studies have confirmed that social-cognition and cultural knowledge are more effectively acquired through problem-solving and social practice (Admiraal, Huizenga, Akkerman, and Dama 2011; Kiili, 2005; Kim, Park, and Baek 2009).

The results of the statistical analysis show that the students were willing to accept using DGBL. The use of information technology in education has been influenced by several learning theories, including behavioural learning theory, social learning theory and cognitive learning theory, and thus has roots in the work of Dewey (1938) and Vygotsky (1978). The present study focused on the relationship among the fourth grade students' "perceived ease of use", "perceived usefulness", "attitude toward use", and "intention to use." The results of this study indicate that when learners are interested in using a computer, he or she would be exposed to environmental education through DGBL to further complete their work or 
tasks better and gain a greater sense of achievement. These results are consistent with prior studies that students can perform better through DGBL (e.g., Huizenga, Admiraal, Akkerman, and Dam 2009; Kearney, 2007; Pillay, 2003).

\section{Conclusions and Suggestions}

This study aimed to explore fourth graders' technology acceptance by applying DGBL to environmental education. Three major findings are relevant to scholars and experts in DGBL. First, the DGBL system is suitable for students of both genders and for students with different levels of prior experience of use. This finding should encourage the spread of the DGBL system. Other studies of integrating information technology into teaching have also suggested an increase in teachers' positive attitudes toward applying DGBL in instruction. as, for example, Latif (2007) points out that digital games are positively accepted among children and teenagers. Additionally, implementing digital games in education enables students to easily absorb content knowledge through its role plays (Zhi and Zhenhong, 2008; Zin et al., 2009). According to the interview results, the students, regardless of gender, expected to have an interesting online game playing experience in environmental education. The students thought that they could play the game and gain environmental knowledge at the same time. As a result, DGBL is feasible for implementation in the environmental education curriculum for elementary school students.

Furthermore, the researchers found that students' "perceived ease of use", "perceived usefulness", "attitude toward use", and "intention to use" reveal a high degree of positive and significant correlation. Ease of use was the primary factor taken into consideration when designing the DGBL system, followed by usefulness. According to the results of interviews, "perceived ease of use" plays an important role in using a DGBL system for environmental education. Furthermore, the results reveal that "perceived ease of use" can predict "perceived usefulness" and "attitude toward use." Likewise, "perceived usefulness" may be able to predict "attitude toward use", and "intention to use." Moreover, "attitude toward use" can predict "intention to use." The findings of the study that TAM can be used to predict the user's intention to use the technology align with the findings of many prior studies (Fang and Zhao 2010; Lai, et al., 2009; Lee, Xiong, \& Hu, 2012; Ngai, et al., 2007; Park, Son, \& Kim, 2012; Tao, et al., 2009).

Finally, the path analysis shows that DGBL acceptance will be directly influenced by learners' "attitudes toward use", "perceived usefulness", and "perceived ease of use." The interview results also reveal that DGBL can enhance students' learning interest and motivation by employing a game, which is familiar to the students, as the DGBL teaching material. Meanwhile, to win the game or to be able to compete with other classmates, most of the students learned to pay more attention in class than ever before and to take notes actively during the class. As a result, the learning effectiveness of the students improved after the seven-week experimental teaching. Therefore, the ease of use should be a priority when embracing DGBL. When designing DGBL for 4th grade elementary school students, researchers should pay more attention to enrich the learning content and ease of use to increase students' intention to use, learning motivation, and learning effectiveness.

\section{Acknowledgment}

The authors would like to gratefully acknowledge that the project was sponsored by the National Science Council, Executive Yuan, ROC (98-2511-S-366-002).

\section{References}

Admiraal, W., Huizenga, J., Akkerman, S., \& Dama G. T. (2011). The concept of flow in collaborative game-based learning. Computers in Human Behavior, 27, 1185-1194.

Ajiboye, J. O., \& Silo, N. (2008). Enhancing Botswana children's environmental knowledge, attitudes and practices through the school civic clubs. International Journal of Environmental \& Science Education, 3(3), 105-114.

Aldrich, C. (2004). Simulations and the future of learning. New York: Pfeiffer. 
Amoako-Gyampah, K., \& Salam, A. F. (2004). An extension of the technology acceptance model in an ERP implementation environment. Information \& Management, 41, 731-745.

Brämer, R. (2003, April). Zurück zur Natur? Die Wald-und-Wiesen-Therapie. Psychologie Heute, 22-28.

Cankaya, S., \& Karamete, A. (2009). The effects of educational computer games on students' attitudes towards mathematics course and educational computer games. Procedia-Social and Behavioral Sciences, 1(1), 145-149.

Cankaya, S., \& Kuzu, A. (2010). Investigating the characteristics of educational computer games developed for children with autism: a project proposal. Procedia-Social and Behavioral Sciences, 9, $825-830$.

Carleton-Hug, H., \& Hug, J. W. (2010). Challenges and opportunities for evaluating environmental education programs. Evaluation and Program Planning, 33, 159-164.

Chang, C. S., Chen, T. S., \& Hsu, W. H. (2011). The study on integrating WebQuest with mobile learning for environmental education. Computers \& Education, 57, 1228-1239.

Cheng, Y. M., Kuo, S. H., Lou, S. J., \& Shih, R. C. (2012). The construction of an online competitive game-based learning system for junior high school students. Turkish Online Journal of Educational Technology, 11(2), 214-227.

Crohn, K., \& Birnbaum, M. (2010). Environmental education evaluation: Time to reflect, time for change. Evaluation and Program Planning, 33, 155-158.

Davis, F. D. (1986). A technology acceptance model for empirically testing new end-user information system: theory and results. Unpublished doctoral dissertation, MIT Sloan of management, Cambridge, MA.

Davis, F. D. (1989). Perceived usefulness, perceived ease of use, and user acceptance of information technology. MIS Quarterly, 13, 319-340.

Davis, F. D., Bagozzi, R. P., \& Warshaw, P. R. (1989). User acceptance of computer technology: a comparison of two theoretical models. Management Science, 35(8), 982-1003.

Dewey, J. (1938). Experience and education. New York, NY: Macmillan.

Disinger, J. F. (1997). An overview. In R. J. Wilke (Ed.), Environmental education teacher resource handbook: A practical guide for K-12 environmental education. Thousand Oaks, CA: Corwin Press.

Fang, X., \& Zhao, F. (2010). Personality and enjoyment of computer game play. Computers in Industry, $61,342-349$.

Fishbein, M., \& Ajzen, I. (1975). Belief, Attitude, Intention, and Behavior: An Introduction to Theory and Research. Reading. MA: Addison-Wesley.

Garcia-Barcena, J. \& Garcia-Crespo, A. (2006). Game based learning: a research on learning content management systems. Proceedings of the 5th WSEAS International Conference on Educational Technology, Tenerife, Canary Islands, Spain, December 16-18.

Garris, R., Ahlers, R., \& Driskell, J. (2002). Games, motivation, and learning: A research and practice model. Simulation \& Gaming, 33(4), 441-467.

Gros, B. (2007). Digital games in education: The design of games-based learning environments Journal of Research on Technology in Education, 40(1), 23-38.

Gruenewald, D. A., \& Manteaw, B. O. (2007). Oil and water still: How no child left behind limits and distorts environmental education in US schools. Environmental Education Research, 13(2), 171-188.

Heimlich, J. E. (2010). Environmental education evaluation: Reinterpreting education as a strategy for meeting mission. Evaluation and Program Planning, 33, 180-185.

Hong, J.-C., Hwang, M.-Y., Hsu, H.-F., Wong, W.-T., \& Chen, M.-Y. (2011). Applying the technology acceptance model in a study of the factors affecting usage of the Taiwan digital archives system. Computers \& Education, 57(3), 2086-2094. Retrieved from http://www.sciencedirect.com/science/article/pii/S0360131511000923 
Hsu, C-L., \& Lu, H-P. (2007). Consumer behavior in online game communities: A motivational factor perspective. Computers in Human Behavior, 23, 1642-1659.

Hsu, S-J. (2005). Significant life experiences fostering environmental activists: A focus on rural-urban and intergenerational differences. Chinese Journal of Science Education, 13(4), 441-463.

Huang, C-H., \& Lin, H-Y. (2008). The research of the structured controversy model in issues-centered approaches applied to environmental education in the elementary school. Journal of National Taichung University:Education, 22(1), 21-50.

Huizenga, J., Admiraal, W., Akkerman, S., \& Dam G. T. (2009). Mobile game-based learning in secondary education: engagement, motivation and learning in a mobile city game. Journal of Computer Assisted Learning, 25, 332-344.

Kaagan, S. S. (1999). Leadership games: Experiential learning for organizational development. Thousand Oaks, CA: Sage.

Kearney, P. (2007). Cognitive assessment of game-based learning. British Journal of Educational Technology, 38(3), 529-531.

Kiili, K. (2005). Digital game-based learning: Towards an experiential gaming model. Internet and Higher Education, 8, 13-24.

Kim, B., Park, H., \& Baek, Y. (2009). Not just fun, but serious strategies: Using meta-cognitive strategies in game-based learning. Computers \& Education, 52, 800-810.

Lai, C-M., Huang, H-M., Liaw, S-S, \& Huang, W-W. (2009). A study of user's acceptance on threedimensional virtual reality applied in medical education. Bulletin of Educational Psychology, 40(3), 341-362.

Latif, R. A. (2007). Understanding Malaysian students as gamers: experience. Proceedings of the $2 n d$ International conference on Digital interactive media in entertainment and arts, 137-141.

Lederer, A. L., Maupin, D. J., Sena, M. P., \& Zhuang, Y. (2000). The technology acceptance model and the World Wide Web. Decision Support Systems, 29, 269-282.

Lee, W., Xiong, L., \& Hu, C. (2012). The effect of Facebook users' arousal and valence on intention to go to the festival: Applying an extension of the technology acceptance model. International Journal of Hospitality Management, 31(3), 819-827.

Lee, Y., Kozar, K., \& Larsen, K. (2003). The technology acceptance model: Past, present, and future. Communications of the Association for Information Systems, 12, 752-780.

Ngai, E. W. T., Poon, J. K. L., \& Chan, Y. H. C. (2007). Empirical examination of the adoption of WebCT using TAM. Computers \& Education, 48, 250-267.

Nicolopoulou, A. (2004). Oyun, Bilissel Gelisim ve Toplumsal Dünya: Piaget, Vygotsky ve Sonras1. Ankara Üniversitesi Esitim Bilimleri Fakültesi Dergisi, 37(2), 137-169.

Pai, F.-Y., \& Huang, K,-I. (2011). Applying the technology acceptance model to the introduction of healthcare information systems. Technological Forecasting \& Social Change, 78, 650-660.

Papargyris, A., \& Poulymenakou, A. (2004). Learning to fly in persistent digital worlds: The case of massively multiplayer online role playing games. ACM SIGGROUP Bulletin, 25(1), 41-49.

Park, Y., Son, H., \& Kim, C. (2012). Investigating the determinants of construction professionals' acceptance of web-based training: An extension of the technology acceptance model. Automation in Construction, 22, 377-386.

Pillay, H. (2003). An investigation of cognitive processes engaged in by recreational computer game players: implications for skills of the future. Journal of Research on Technology in Education, 34, 3, $336-350$.

Polancic, G., Hericko, M., \& Rozman, I. (2010). An empirical examination of application frameworks success based on technology acceptance model. The Journal of Systems and Software, 83, 574-584.

Prensky, M. (2001). Digital game-based learning. New York: McGraw-Hill. 
Ramsey, J. M., \& Hungerford, H. R. (1989). The effects of issue investigation and action training on environmental behaviors in seventh grade students. Journal of Environmental Education, 20(4), 2934.

Reconstruction Council (2009). Morakot Post-Disaster. Retrieved June 6, 2011, from http://88flood.www.gov.tw/work.php\#8

Schoenfeld, C.A. (1975) National environmental education perspectives, In: R. J. H. Schafer \& J. F. Disinger (Eds.), Environmental Education: perspectives and prospectives (pp. 43-45). Columbus, OH: ERIC/SMEAC.

Shroff, R. H., Deneen, C. D. \& Ng, E. M. W. (2011). Analysis of the technology acceptance model in examining students' behavioural intention to use an e-portfolio system. Australasian Journal of Educational Technology, 27(4), 600-618. Retrieved from http://www.ascilite.org.au/ajet/ajet27/shroff.html

Squire, K., \& Steinkuehler, C. (2005). Meet the gamers. Library Journal, 130(7), 38-42.

Stapp, W. B. (1969). The concept of environmental education. Journal of Environmental Education, 1(1), 30-31.

Stefanescu, C., Chirita, V., Chirita, R. \& Chele, G. (2007). Network identity, the internet addiction and Romanian teenagers. Proceedings of the 4th WSEAS/IASME International Conference on Engineering Education, Agios Nikolaos, Crete Island, Greece, July 24-26.

Tao, Y-H., Cheng, C-J., \& Sun, S-Y. (2009). What influences college students to continue using business simulation games? The Taiwan experience. Computers \& Education, 53, 929-939.

Teo, T. (2010). Examining the influence of subjective norm and facilitating conditions on the intention to use technology among pre-service teachers: a structural equation modeling of an extended technology acceptance model. Asia Pacific Educ. Rev, 11, 253-262.

Teo, T., Lee, C. B., Chai, C. S., \& Wong, S. L. (2009). Assessing the intention to use technology among pre-service teachers in Singapore and Malaysia: A multigroup invariance analysis of the Technology Acceptance Model (TAM). Computers \& Education, 53, 1000-1009.

Ürey, M., Çolak, K., \& Okur, M. (2009). Regional differences in environment education of primary education in terms of teacher conceptions. Original Research Article. Procedia - Social and Behavioral Sciences, 1(1), 795-799.

Uzunboylu, H., Cavus, N., \& Ercag, E. (2009). Using mobile learning to increase environmental awareness. Computers \& Education, 52, 381-389.

Van Velsor, S. W. (2004). A qualitative investigation of the urban minority adolescent experience with wildlife. $\mathrm{PhD}$ thesis, University of Missouri.

Vasiliou, A. \& Economides, A. A. (2007). Game-based learning using MANETs. Proceedings of the 4th WSEAS/IASME International Conference on Engineering Education, Agios Nikolaos, Crete Island, Greece, July 24-26.

Vygotsky, L. S. (1978). Mind in society: The development of higher psychological processes. Cambridge, MA: Harvard University Press.

Yang, J. C., Chien, K. H., \& Liu, T. C. (2012). A digital game-based learning system for energy education: an energy conservation pet. The Turkish Online Journal of Educational Technology, 11(2), 29-37.

Yurttaş, G. D., \& Sülün, Y. (2010). What are the most important environmental problems according to the second grade primary school students? Procedia - Social and Behavioral Sciences, 2(2), 1605-1609.

Zhang, H., \& Ye, U-T. (2010). The meaning of primary schools to green land supply in the concentrated urban area: underneath environmental education. Journal of Environmental Education Research, 8(1), 95-121.

Zhi, H., \& Zhenhong, Z. (2008). Integration of game elements with role play in collaborative learning-a case study of quasi-GBL in Chinese higher education. Edutainment, 427-435. 
Zin, N. A. M., Jaafar, A., \& Yue, W. S. (2009). Digital game-based learning (DGBL) model and development methodology for teaching history. Wseas Transactions on Computers, 2(8), 322-333.

Corresponding author: Ru-Chu Shih, vincent@npust.edu.tw

Australasian Journal of Educational Technology (C) 2013.

Please cite as: Cheng, Y.-M., Lou, S.-J., Kuo, S.-H., \& Shih, R.-C. (2013). Investigating elementary school students' technology acceptance by applying digital game-based learning to environmental education. Australasian Journal of Educational Technology. 29(1), 96-110. 